\title{
Effects of Oxygenated Lanosterol Analogs on Cholesterol Biosynthesis from Lanosterol ${ }^{11}$
}

\author{
Yoshiko Sonoda and Yoshiniro Sato* \\ Kyoritsu College of Pharmacy, Shibakoen 1-chome, Minato-ku, Tokyo 105, Japan
}

(Received October 6, 1982)

\begin{abstract}
The effects of oxygenated lanosterol derivatives $(1-14)$ on cholesterol biosynthesis from $\left[24^{-3} \mathrm{H}\right]$-lanosterol were tested in $10000 \times \boldsymbol{g}$ supernatant $\left(\mathrm{S}_{10}\right)$ fraction of rat liver homogenate $(\mathrm{RLH})$. Among the derivatives studied, 7-oxo-24,25-dihydrolanosterol (11) was most active in depressing cholesterol biosynthesis from lanosterol. The inhibitory activities of these derivatives on cholesterol synthesis are discussed in relation to the position and stereochemistry of the oxygen group on the side chain and the sterol nucleus.

Keywords-cholesterol biosynthesis; $\left[24{ }^{3} \mathrm{H}\right]$-lanosterol; oxygenated lanosterol derivative; 7-oxo-24,25-dihydrolanosterol; $24(R), 25$-oxidolanosterol; $24(S)$, 25-oxidolanosterol; rat liver homogenate; inhibition of lanosterol demethylation
\end{abstract}

Some oxygenated sterols ${ }^{2)}$ are potent inhibitors of 3-hydroxy-3-methylglutary-CoA (HMG-CoA) reductase and lanosterol demethylation in HTC cells. In a previous paper ${ }^{3)}$ we demonstrated that in $\mathrm{S}_{\mathbf{1 0}}$ fraction of rat liver homogenate some lanosterol analogs with different sizes of side chain depressed the rate of cholesterol biosynthesis from lanosterol. This paper describes the effects of fourteen oxygenated lanosterol derivatives on cholesterol synthesis from lanosterol under the same conditions as described previously. ${ }^{3)}$

Inhibitory potency was influenced by the location of the hydroxy function or ketone function on the side chain and by the introduction of an oxygen group into the nucleus. It is of interest that 7-oxo-24,25-dihydrolanosterol (11) was most active in depressing cholesterol biosynthesis from lanosterol.

\section{Materials and Methods}

Synthesis of $22 R$ - and $22 S$-hydroxylanosterol were reported previously.4) $24 R$ - and $24 S$-Hydroxy24,25 -dihydrolanosterol, ${ }^{5)} 24(R), 25$ - and $24(S), 25$-oxidolanosterol, ${ }^{5}$ ) 24-oxo-24,25-dihydrolanosterol, ${ }^{6)} 26$ hydroxylanosterol, ${ }^{7)} 3 \beta$-hydroxylanosta-8,24-dien-26-al, ${ }^{7)}$ 7-oxo-24,25-dihydrolanosterol ${ }^{8)}$ were prepared as described previously.

7a-Hydroxy-24,25-dihydrolanosterol-This material was synthesized by the method of Shoppee et al. ${ }^{9)}$ Recrystallization from $\mathrm{MeOH}$ gave colorless needles, $\mathrm{mp} 143-143.5^{\circ} \mathrm{C}$. Proton magnetic resonance $(\mathrm{PMR}) \delta(\mathrm{ppm}): 0.60\left(3 \mathrm{H}, \mathrm{s}, 18-\mathrm{CH}_{3}\right), 0.81\left(3 \mathrm{H}, \mathrm{s}, 4 \beta-\mathrm{CH}_{3}\right), 0.85\left(6 \mathrm{H}, \mathrm{d}, 26\right.$ and $\left.27-\mathrm{CH}_{3}, J=6.5 \mathrm{~Hz}\right), 0.94(3 \mathrm{H}$, $\left.\mathrm{s}, 19-\mathrm{CH}_{3}\right), 1.02\left(6 \mathrm{H}, \mathrm{s}, 14\right.$ and $\left.4 \alpha-\mathrm{CH}_{3}\right), 3.16-3.40(1 \mathrm{H}, \mathrm{m}, 3-\mathrm{H}), 4.12-4.24\left(1 \mathrm{H}, \mathrm{m}, 7-\mathrm{H}, W_{1 / 2}=7 \mathrm{~Hz}\right)$. Mass spectrum (MS) $m / e: 444\left(\mathrm{M}^{+}\right)$.

Lanosta-8,24-dien-3a-ol $\left.{ }^{10}\right)$ (3-Epilanosterol) (14)- $-\mathrm{NaBH}_{4}(0.2 \mathrm{~g})$ was added to a solution of lanosta8,24-dien-3-one $(0.1 \mathrm{~g})$ in $\mathrm{MeOH}(30 \mathrm{ml})$ and the reaction mixture was stirred for $1 \mathrm{~h}$ at $0^{\circ} \mathrm{C}$. Ice-water was added to this reaction mixture and the whole was extracted with $\mathrm{CH}_{2} \mathrm{Cl}_{2}$, washed with water, dried over sodium sulfate and evaporated to dryness. The residue was column-chromatographed on silica gel (10 g). Elution with benzene gave a solid $(6 \mathrm{mg})$, which was recrystallized from $\mathrm{MeOH}$ to give colorless needles of 14, $\mathrm{mp} 125-125.5^{\circ} \mathrm{C}$. PMR $\delta(\mathrm{ppm}): 0.70\left(3 \mathrm{H}, \mathrm{s}, 18-\mathrm{CH}_{3}\right), 0.88\left(6 \mathrm{H}, \mathrm{s}, 4\right.$ and $\left.14-\mathrm{CH}_{3}\right), 0.99\left(3 \mathrm{H}, \mathrm{s}, 4-\mathrm{CH}_{3}\right), 1.00$ $\left(3 \mathrm{H}, \mathrm{s}, 19-\mathrm{CH}_{3}\right), 1.60\left(3 \mathrm{H}, \mathrm{s}, 26\right.$ or $\left.27-\mathrm{CH}_{3}\right), 1.68\left(3 \mathrm{H}, \mathrm{s}, 26\right.$ or $\left.27-\mathrm{CH}_{3}\right), 3.40-3.52\left(1 \mathrm{H}, \mathrm{m}, 3-\mathrm{H}, W_{1 / 2}=8 \mathrm{~Hz}\right)$, $5.18(1 \mathrm{H}, \mathrm{t}, 24-\mathrm{H})$. MS m/e: $426\left(\mathrm{M}^{+}\right)$.

Further elution with benzene gave a solid $(70 \mathrm{mg})$, which was identified as lanosterol.

Assays for Effects on Cholesterol Biosynthesis from Lanosterol__Experiments to determine the effects of the test compounds on cholesterol biosynthesis from $18 \mu \mathrm{M}\left[24-{ }^{3} \mathrm{H}\right]$-lanosterol were performed at a concentration of $40 \mu \mathrm{M}$ oxygenated lanosterol derivative in $\mathrm{S}_{10}$ fraction $(19.5-20.6 \mathrm{mg}$ protein $/ \mathrm{ml})$ of $\mathrm{RLH}$ as described previously. ${ }^{3)}$ 
<smiles>[R]C(C)C(O)CC=C(C)C</smiles><smiles>[R]C(C)CCC(=O)C(C)C</smiles><smiles>[R]C(C)CCC=C(C)CO</smiles><smiles>[R]C(C)[C@@H](O)CC=C(C)C</smiles><smiles>[R]C(C)CC[C@]1(C)OC1(C)C</smiles><smiles>[R]C(C)CCC=C(C)C=O</smiles><smiles>[R]C(C)CC[C@@H](O)C(C)C</smiles><smiles>[R]C(C)CC[C@@H]1OC1(C)C</smiles><smiles>[R]C(C)CCC(O)C(C)C</smiles><smiles>[R]C(C)CCCC(C)(C)O</smiles><smiles>CCC1CCC2(C)C3=C(CCC12C)C1(C)CCC(O)C(C)(C)C1CCC3C</smiles><smiles>[R]C1=C2C(=C3CCC4(C)C(C(C)CCCC(C)C)CCC4(C)C13C)CCC(O)C2(C)C</smiles>

11: $\mathrm{R}=0$

12 : $R=\alpha-O H$

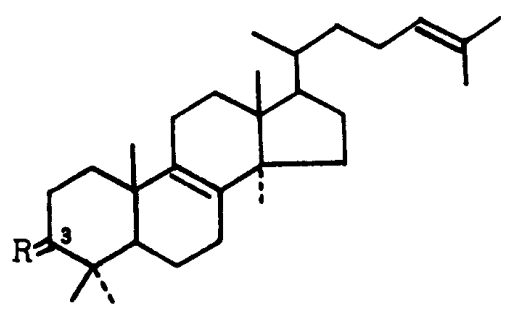

13 : $\mathrm{R}=0$

14: $R=\alpha-O H$

15: $R=\beta-O H$

Chart 1

\section{Results and Discussion}

The structures of oxygenated lanosterol derivatives used in this study are shown in Chart 1 . Table I shows the effects of fourteen compounds on cholesterol biosynthesis from lanosterol. At the concentration of $40 \mu \mathrm{m}$, the compounds with a hydroxy function or ketone function at carbon $26,25,24$, or 7 of lanosterol or 24,25-dihydrolanosterol, except for the 26aldehyde compound (10), effectively depressed the rate of cholesterol synthesis from lanosterol in $\mathrm{S}_{10}$ fraction of RLH. Among them, 7-oxo-24,25-dihydrolanosterol (11) was remarkably active and showed $98 \%$ inhibition. On the other hand, 26-aldehyde compound (10) showed no activity. $22 R$ - and $22 S$-Hydroxylanosterol ( 1 and 2$)$ showed moderate inhibitions (17 and $21 \%$, respectively). In the case of the 7 -keto compound (11), recovery yield of the substrate was $92 \%$, suggesting that 11 may inhibit 14-demethylation of lanosterol. The relative 
inhibitory potencies of the side-chain-hydroxylated sterols were related to the location of the hydroxy function. The order of inhibitory activity was 26 -hydroxylanosterol $>25$-hydroxy24,25 -dihydrolanosterol $>24 R$ - and $24 S$-hydroxy-24,25-dihydrolanosterol $>22 R$ - and $22 S$ hydroxylanosterol.

TABLE I. Cholesterol Biosynthesis during Incubation of $\mathrm{S}_{10}$ Fraction of Rat Liver Homogenate with $\left[24-{ }^{3} \mathrm{H}\right]$ Lanosterol in the Presence of Oxygenated Lanosterol Derivatives

\begin{tabular}{|c|c|c|c|}
\hline Compound & $\begin{array}{c}\text { Lanosterol } \\
\text { Fr. }(\%)\end{array}$ & $\begin{array}{c}\text { Cholesterol } \\
\text { Fr. (1/1) }\end{array}$ & $\begin{array}{l}\text { Inhibition } \\
\text { (兴) }\end{array}$ \\
\hline None (control) & 24.8 & 22.8 & - \\
\hline $22 R \cdot$ Hydroxy $\cdot \mathrm{L}(\mathbf{1})$ & 34.0 & 19.0 & 17 \\
\hline $22 S$-Hydroxy-L (2) & 41.2 & 18.1 & 21 \\
\hline $24 R$-Hydroxy-DHL (3) & 68.7 & 12.4 & 46 \\
\hline $24 S$-Hydroxy-DHL (4) & 62.3 & 12.9 & 43 \\
\hline 24-Oxo-DHL (5) & 62.9 & 13.0 & 43 \\
\hline $24(R), 25$-Oxido-L $(6)$ & 50.6 & 10.3 & 55 \\
\hline $24(S), 25$-Oxido-L ( 7$)$ & 52.2 & 8.9 & 61 \\
\hline 25-Hydroxy-DHL $(\mathbf{8})^{a !}$ & 71.8 & 8.1 & 64 \\
\hline 26-Hydroxy-L $(9)$ & 81.0 & 5.7 & 75 \\
\hline 26-Aldehyde-L $(\mathbf{1 0})^{h_{1}}$ & 18.2 & 26.8 & 0 \\
\hline 7-Oxo-DHL (11) & 92.3 & 0.4 & 98 \\
\hline $7 \alpha$-Hydroxy-DHL (12) & 60.1 & 12.0 & 47 \\
\hline 3.Oxo-L $(13)^{6}$ & 27.6 & 19.2 & 16 \\
\hline 3-Epi-L (14) & 40.6 & 15.1 & 34 \\
\hline $\mathrm{L}(\mathbf{1 5})^{a t}$ & 34.5 & 17.6 & 23 \\
\hline
\end{tabular}

$\left[24 \cdot{ }^{3} \mathrm{H}\right]$-Lanosterol $(90600 \mathrm{dpm} ; 0.43 \mu \mathrm{Ci} / \mu \mathrm{mol}, 18 \mu \mathrm{M})$ was incubated with rat liver $\mathrm{S}_{10}$ fraction at $37^{\circ} \mathrm{C}$ for $3 \mathrm{~h}$. The incubation mixture contained, in a total volume of $5 \mathrm{ml}, 4 \mathrm{ml}$ of $\mathrm{S}_{10}$ fraction and cofactors. Incubation was started by the addition of the substrate and test compounds as an emulsion $(0.1 \mathrm{ml})$ with Tween $80(3 \mathrm{mg}){ }^{13}$ ) Analytic methods for incubation products and calculation of the percentage inhibition were described previously." Each incubation was carried out in triplicate and the standard deviation of each value listed was less than 5 percent. DHL and L denote 24,25-dihydrolanosterol and lanosterol, respectively.

a) These compounds were tested previously, but were tested again as references; the results differ from those reported previously."

b) 26 -Aldehyde-L denotes $3 \beta$-hydroxylanosta-8,24-dien-26-al

c) 3-Oxo-L denotes lanosta-8,24-dien-3-one.

Some of these oxygenated lanosterol derivatives, 25-hydroxy-24,25-dihydrolanosterol ${ }^{(8)^{11)}}$ and $24(S), 25$-oxidolanosterol $(7),{ }^{12)}$ have been reported to be converted efficiently to the corresponding cholesterol derivatives, 25-hydroxycholesterol and 24(S),25-epoxycholesterol. The former compound has been shown to exhibit inhibitory activity on incubation with $\mathrm{S}_{\mathbf{1 0}}$ fraction of RLH. These results suggest that the oxygenated lanosterol derivatives may be transformed to metabolites which exhibit inhibitory activities.

Further, the transformation of the $3 \beta$-hydroxy group (15) to a $3 \alpha$-hydroxy group (14) or 3-keto group (13) caused a small change in the inhibitory effect. The order of inhibitory activity was 3 -epilanosterol $>$ lanosterol $>$ lanosta-8,24-dien-3-one. These results suggest that there is some steric and electrostatic requirement around position $\mathrm{C}-3$ of the $\mathrm{A}$ ring for interaction with the enzymes concerned. Our hypothesis is that the 7-keto compound (11) acts by binding to a protein related to lanosterol 14-demethylase.

In summary, it was demonstrated that the inhibitory effects of sterols on cholesterol synthesis are largely related to the position of the oxygen group on the side chain and the sterol skeleton.

Acknowledgement This work was supported in part by a grant from Mishima Kaiun Memorial Foundation. 


\section{References and Notes}

1) Y. Sato, Y. Sonoda, M. Morisaki, and N. Ikekawa, Chem. Pharm. Bull., 31, 1765 (1983).

2) a) P.R. Ortiz de Montellano, J.P. Beck, and G. Ourisson, Biochem. Biophys. Res. Commun., 90, 897 (1979); b) G.F. Gibbons, C.R. Pullinger, H.W. Chen, W.K. Cavenee, and A.A. Kandustch, J. Biol. Chem., 255, 395 (1980).

3) Y. Sato and Y. Sonoda, Chem. Pharm. Bull., 29, 2604 (1981).

4) Y. Sonoda and Y. Sato, Chem. Pharm. Bull., 31, 907 (1983).

5) R.B. Boar, D.A. Lewis, and J.F. McGhie, J. Chem. Soc., Perkin Trans. 1, 1972, 2231.

6) L.H. Briggs, J.P. Bartley, and P.S. Rutledge, J. Chem. Soc., Perkin Trans. 1, 1973, 806.

7) F. Nicotra, F. Ronchetti, and G. Russo, J. Labelled Compounds, 14, 541 (1978).

8) J.T. Pinkey, B.J. Ralph, J.J.H. Simes, and M. Wootton, A ust. J. Chem., 23, 2141 (1970).

9) C.W. Shoppee, J.C. Coll, and R.E. Lack, J. Chem. Soc., Perkin Trans. 1, 1968, 1581.

10) M. Rhohmer, P. Bouvier, and G. Ourisson, Eur. J. Biochem., 112, 557 (1980).

11) J.A. Nelson, S.R. Steckbeck, and T.A. Spencer, J. Biol. Chem., 256, 1067 (1981).

12) S.R. Steckbeck, J.A. Nelson, and T.A. Spencer, J. Am. Chem. Soc., 104, 893 (1982).

13) This surfactant has been used to emulsify sterols in studies on sterol biosynthesis: cf. a) M. Fryberg, A.C. Oehlschlager, and A.M. Unrau, J. Am. Chem. Soc., 95, $5747(1973)$; b) G.F. Gibbons, Biochem. $J ., 144,59(1974)$. 